\title{
El ve El Bileği Yerleşimli Tendon Kılıfının Dev Hücreli Tümörü: 42 Hastanın Retrospektif Analizi
}

\author{
Sercan ÇAPKIN, Tufan KALELI
}

Bursa Uludağ Üniversitesi Tıp Fakültesi, Ortopedi ve Travmatoloji Anabilim Dalı, El Cerrahisi Bilim Dalı, Bursa.

\section{ÖZET}

Tendon kılıfının dev hücreli tümörü (TKDHT), ganglion kistinden sonra elde en sık görülen benign yumuşak doku tümörüdür. Çalışmamızda el ve el bileği yerleşimli TKDHT nedeniyle ameliyat edilen 42 hastanın demografik, klinik, radyolojik ve histopatolojik özellikleri ile cerrahi sonrası nüks oranları güncel literatür eşliğinde tartışıldı. Çalışmamızda; kadın/erkek oranı: $2.5 / 1$, ortalama yaş 40.23 \pm 14.86 , rın \%64.28'inde tümör volar bölgeye lokalize, elde en sık lokalizasyon başparmak (\%33.3), parmaklarda ise en sık lokalizasyon proksimal falanks $(\% 35,71)$ olup, bulgular literatür verileriyle uyumluydu. Serimizde şikayetin başlangıcından cerrahiye kadar geçen ortalama zaman 5.4 ay olarak bulundu. Nüks gelişen 2 hastada (\%4.76) tümör volar bölgeden başlayıp dorsal bölgeye doğru uzanmaktaydı ve muhtemel nüks nedeni geride satellit lezyon kalmasıydı. Sonuç olarak TKDHT benign karakterine rağmen lokal agresif bir tümördür. Nüks oranlarını azaltmak için büyütücü gözlük altında, geniș bir cerrahi sahada, titiz bir cerrahi uygulanmalı, özellikle hem volar hem de dorsal bölgeye lokalize olan tümörlerde geride satellit lezyon bırakmamak için ayrı insizyonlar kullanılması akılda bulundurulmalıdır.

Anahtar Kelimeler: Tendon klıfı. Dev hücreli tümör. El ve El Bileği.

Giant Cell Tumour of the Tendon Sheath of the Hand and Wrist: Retrospective Analysis of 42 Patients

\begin{abstract}
Giant cell tumour of the tendon sheath (GCTTS) is the second most common benign soft tissue tumour of the hand after the ganglion cyst. In our study, demographic, clinical, radiological and histopathological features and recurrence rates of 42 patients who had been operated for hand and wrist located GCTTS were discussed with the current literature. In our study; female/male ratio: 2.5/1, average age 40.23 \pm 14.86 , $64.28 \%$ of patients localized to the tumour volar side, the most common localization thumb (33.3\%) in the hand, the most common localization of the proximal phalanx in the fingers (35.71\%), findings were consistent with literature data. In our series, the average time from the beginning of the complaint to surgery was found to be 5.4 months. In 2patients (4.76\%) who developed recurrence, the tumours started from the volar side was reaching to the dorsal side, and the reason for the possible recurrence was the remaining satellite lesions. As a result, GCTTS is a locally aggressive tumour despite its bening character. To reduce the recurrence rate, a meticulous surgery should be performed under magnifying loupe, in a large surgical area, especially in tumours that are localized to both the volar and dorsal sides, and separate incisions should be considered in order not to leaving behind satellite lesions.
\end{abstract}

Key Words: Tendon sheath. Giant cell tumour. Hand and Wrist.

Tendon kıllfinın dev hücreli tümörü (TKDHT), ganglion kistinden sonra elde en sık görülen benign yumuşak doku tümörüdür ${ }^{1,2}$. İlk kez 1852 y1lında Chassaignac tarafindan 'tendon kılıfinın malign tümörü' olarak tanımlanmıştır' ${ }^{3} 1897$ yılında Targett tarafindan 'ten-

Geliş Tarihi: 30 Kasım 2018

Kabul Tarihi: 06 Mart 2019

Dr. Sercan ÇAPKIN

Bursa Uludağ Üniversitesi Tıp Fakültesi,

Ortopedi ve Travmatoloji Anabilim Dalı,

El Cerrahisi Bilim Dalı,

16059, Görükle/BURSA

Tel.: 05068427596

E-posta: sercancapkn@gmail.com don kılıfının dev hücreli tümörü’ ismi ilk kez kullanılmıştır ${ }^{4}$. Daha sonra; lokalize nodüler tenosinovit, pigmente villonodüler tenosinovit, proliferatif sinovit, benign sinoviyoma, ksantoma, ksantogranüloma, miyeloksantoma ve tendon kıllfinın dev hücreli tümörü gibi ismlerle anılmıştır ${ }^{5-8}$. Bütün bu adlandırılmış tümörlerde, çok çekirdekli dev hücrelerin bulunması benzer histolojik özelliklere sahip olduklarını göstermektedir. Ancak bu kadar fazla isimle anılması etyolojisinin tam olarak aydınlatılmadığını göstermektedir. Travma, inflamasyon, immün reaksiyon, metabolik hastalıklar ve neoplastik orjin etyolojide suçlanmakta$\mathrm{d}^{9} \mathrm{r}^{9-12}$. Etyolojideki belirsizliğe rağmen; klinik, radyolojik ve histopatolojik özellikleri ile cerrahi tedavisi ayrıntılı bir şekilde literatürde tanımlanmıştır. 
Dev hücreli tümörler 1968 yılında Byers ve ark. tarafindan sıklıkla elde görülen lokalize nodüler tip ve diz gibi büyük eklemlerde görülen diffüz tip olarak ikiye ayrılmıştır $^{13}$. El yerleşimli olanlar genellikle yavaş büyüyen, ağrısız benign yumuşak doku lezyonlarıdır. Ancak benign karakterine rağmen cerrahi eksizyon sonrası yüksek lokal nüks oranları bildirilmiştir ${ }^{14,15}$.

Bu makalede el ve el bileği yerleşimli TKDHT nedeniyle ameliyat edilen 42 hastanın demografik, klinik, radyolojik ve histopatolojik özellikleri ile cerrahi sonrası nüks oranları güncel literatür eşliğinde tart1Şılmıştır.

\section{Gereç ve Yöntem}

Çalışmamıza başlamadan önce Bursa Uludağ Üniversitesi Tip Fakültesi Klinik Araştırmalar Etik Kurulu'ndan onay alındı (Karar no: 2018-20/6) Ekim 2005Ocak 2018 tarihleri arasında el ve el bileği yerleşimli TKDHT nedeniyle ameliyat edilen ve histopatolojik tanısı doğulanan 42 hasta retrospektif olarak değerlendirildi.

Rejyonel ya da genel anestezi uygulanan hastaların cerrahi işlemi, kola uygulanan turnike altında $4.3 \mathrm{~kat}$ büyütmeli cerrahi loop kullanılarak yapıldı. Cerrahi yaklaşım tümörün lokalizasyonuna göre belirlendi. Volar yerleşimli tümörlerde modifiye Brunner insizyonu, dorsal yerleşimli tümörlerde ise eğrisel bir insizyon kullanıldı. Tüm hastalarda bitişik tendon ve nörovasküler yapılar korunarak marjinal eksizyon uyguland1.

Hastaların tıbbi kayıtları incelenerek; yaş, cinsiyet, taraf, lokalizasyon, klinik ve radyolojik bulgular, tümörün histopatolojik özellikleri, uygulanan cerrahi tedavi, nüks ve komplikasyon oranları gibi veriler elde edildi. Veriler, Microsoft Excel programına girilerek ortalama ve standart hata değerleri hesaplandı. Sonuçlar literatür eşliğinde tartışıldı.

\section{Bulgular}

Tablo I'de hastaların demografik ve klinik verileri özetlenmiştir. Hastaların 12'si erkek, 30'u kadındı. Yaş dağılımı 15-68 yıl arasında değişmekte olup, cerrahi sırasında ortalama yaş $40.23 \pm 14.86$ olarak bulundu. Hastaların 20' sinde tümör sağ, 22'sinde ise sol el veya el bileğinde lokalizeydi. Hastaların hiçbirinde travma öyküsü yoktu. Hastalar genellikle ağrısız yumuşak doku kitlesi ile başvurdu (Şekil 1). 7 hastada (\%16.6) hafif ağrı ve hassasiyet, 4 hastada (\%9.52) parmak ucunda uyuşma ve karıncalanma gibi nörolojik semptomlar, 5 hastada (\%11.9) ise eklem hareketlerinde kısıtlılık saptandı. Bulguların süresi 1-12 ay arasında değişmekte olup, ortalama 5.4 aydı. Ameliyat öncesi tüm hastaların standart ön-arka/lateral grafileri ve manyetik rezonans görüntüleri elde edildi. Radyolojik olarak hiçbir hastada kemik tutulumu gözlenmedi. 27 hastada (\%64.28) tümör volar tarafta, 11 hastada (\%26.19) dorsal tarafta, 4 (\%9.52) hastada ise hem volar hem de dorsal tarafta lokalizeydi (Tablo II). En sık yerleşim yeri 14 hasta (\%33.3) ile başparmak iken, parmakta en s1k görüldüğü lokalizasyon 15 hasta (\%35.71) ile proksimal falanks düzeyiydi (Şekil 2).

Tablo I. Hastaların demografik ve klinik verileri.

\begin{tabular}{|c|c|}
\hline Hasta sayısı & 42 \\
\hline Cinsiyet & $\begin{array}{l}\text { Erkek: } 12 \text { (\%28.57), kadın: } 30 \\
\text { (\%71.43) }\end{array}$ \\
\hline Ortalama yaş & $40.23 \pm 14.86$ (dağııım:15-68 yıl) \\
\hline Taraf & Sol: 20 (\%47.62), sağ: 22 (\%52.38) \\
\hline $\begin{array}{l}\text { Şikâyetin başlangıcından } \\
\text { cerrahiye kadar geçen } \\
\text { ortalama zaman (ay) }\end{array}$ & $5.4 \pm 3.25$ (dağılım: $1-12$ ay) \\
\hline Ortalama çap (cm) & $1.85 \pm 1.05$ (dağılım: 0.4-4cm) \\
\hline Komplikasyon & $8(\% 19.04)$ \\
\hline Nüks & $2(\% 4.76)$ \\
\hline $\begin{array}{l}\text { Ortalama takip süresi } \\
\text { (yıl) }\end{array}$ & $6 \pm 3.04$ \\
\hline
\end{tabular}

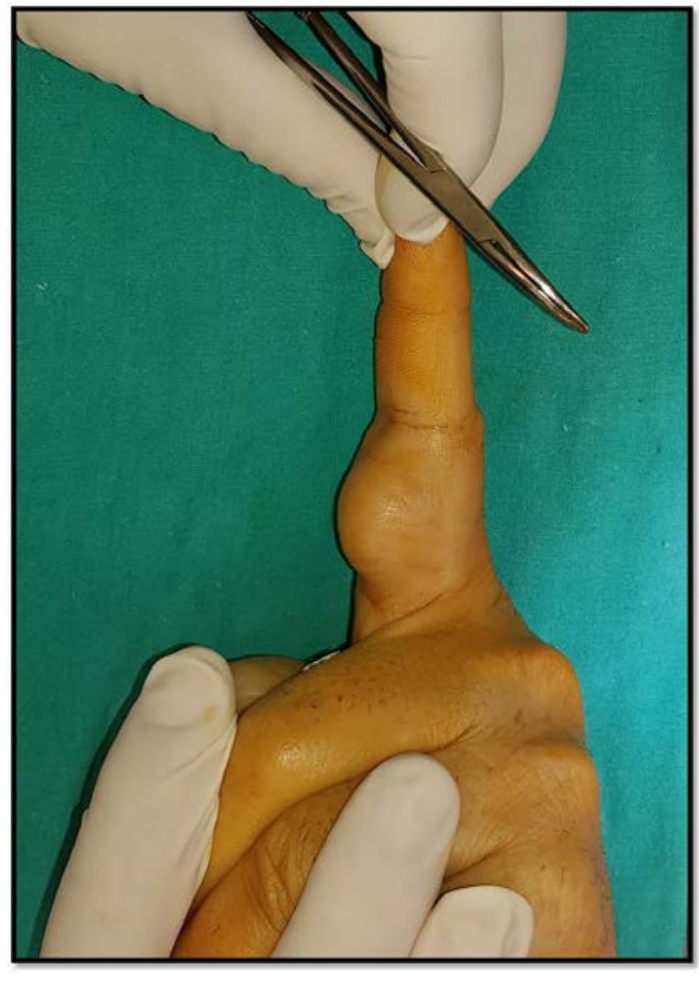

Şekil 1.

Ameliyat öncesi sol el 2. parmak proksimal falanks düzeyindeki tümörün görünümü. 
Tablo II. Tümörlerin el ve el bileğindeki anatomik dağılımı.

\begin{tabular}{|lcccc|}
\hline & Volar & Dorsal & Volar+Dorsal & Toplam \\
\hline 1. Parmak & 11 & 2 & 1 & $14(\% 33.3)$ \\
2. Parmak & 5 & 2 & 0 & $7(\% 16.6)$ \\
3. Parmak & 5 & 1 & 2 & $8(\% 19.04)$ \\
4. Parmak & 1 & 1 & 0 & $2(\% 4.76)$ \\
5. Parmak & 2 & 2 & 1 & $5(\% 11.9)$ \\
El & 2 & 1 & 0 & $3(\% 7.14)$ \\
El bileği & 1 & 2 & 0 & $3(\% 7.14)$ \\
\hline Toplam & $27(\% 64,28)$ & $11(\% 26,19)$ & $4(\% 9.52)$ & $42(\% 100)$ \\
\hline
\end{tabular}

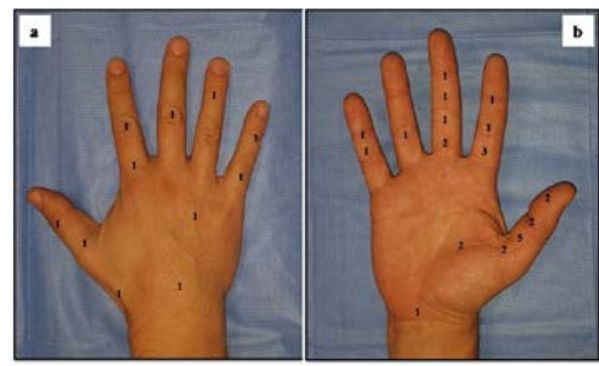

Şekil 2.

Dorsalde tümörlerin anatomik dă̆ılımı (a), Volarde tümörlerin anatomik dağılımı (b).

(Şekil 2'de 38 vakanın yerleşim yeri gösterilmiştir, 4 vaka hem volar hem de dorsal bölgede yer aldığından şekilde gösterilmemiştir)

Patoloji raporlarından ölçülen maksimum çap değerlerinin ortalaması alınarak ortalama tümör çapı hesap-

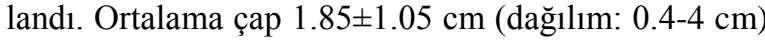
olarak bulundu. Tümörler genellikle ince bir psödokapsül ile çevrelenmişti (Şekil 3). Mikroskobik olarak tüm olgularda değişen oranlarda çok çekirdekli dev hücreler, histiyositler ve hemosiderin depositleri görüldü. Olguların hiçbirinde atipik mitoza rastlanmadı.

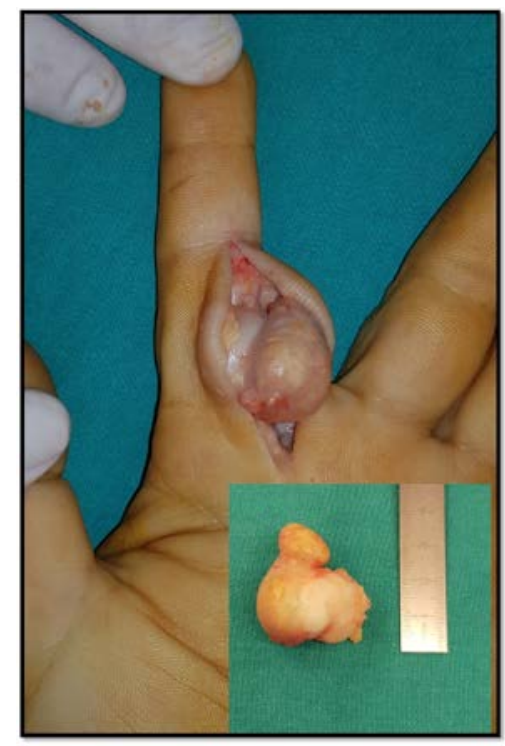

Şekil 3.

Ameliyat esnasında tümörün makroskopik görünümü.
Cerrahi sonrası 2 hastada (\%4.76) yüzeyel yara enfeksiyonu, 2 hastada $(\% 4,76)$ proksimal interfalangeal eklemde sertlik, 4 hastada (\%9.52) ise parmak ucunda hipoestezi gözlendi. Yara yeri enfeksiyonu gelişen hastalar lokal pansumanı ile iyileşti. Hipoestezi şikâyeti olan 4 hastanın semptomları cerrahiden bir ay sonra düzeldi. Proksimal interfalangeal eklemde sertlik olan hastalar fizik tedavi sonrası iyileşti. Ortalama 6 yıllık takip süresi içinde 2 hastada $(\% 4.76)$ nüks gelişti. $\mathrm{Bu} 2$ hastada tümör volar taraftan başlayarak dorsal tarafa doğru uzanmaktaydı. Nüks gelişen hastalara tekrar operasyon önerildi ancak hastalar operasyonu kabul etmedi.

\section{Tartışma ve Sonuç}

TKDHT; genellikle ağrısız, yavaş büyüyen, multilobüler kitle olarak karşımıza çıkar. Kadınlarda daha fazla olmak üzere sıklıkla 30-50 yaşları arasında görülür ${ }^{16,17}$. Özelikle işaret parmağı olmak üzere en sık elin ilk üç parmağında lokalize olduğu bildirilmiştir ${ }^{18-21}$. El parmaklarında en çok distal interfalangeal eklem ve proksimal falanks seviyesinde görülmekle birlikte elin volar tarafına yerleşimi dorsal taraftan daha sıktır. Literatürde volar taraf yerleşimi \%44-70 arasında rapor edilmiştir ${ }^{19-21}$. Çalışmamızda; kadın/erkek oranı: 2.5 , ortalama yaş 40.23 , hastaların $\% 64.28$ 'inde tümör volar tarafa lokalize, elde en sık lokalizasyon başparmak $(\% 33,3)$, parmaklarda ise en s1k lokalizasyon proksimal falanks (\%35,71) olup bulgular literatür verileriyle uyumluydu. Tümörün yavaş büyüyen doğası nedeniyle tanı genellikle semptomların başlangıcından 6 ay ile 2.5 y1l arasında konur ${ }^{20,21}$. Serimizde şikayetin başlangıcından cerrahiye kadar geçen ortalama zaman 5.4 ay olarak bulundu.

Direkt grafi, özellikle kortikal erozyon ve subkondral kist gibi kemik tutulumunun olduğu diğer tümörlerin ayırıcı tanısında önemlidir. Radyolojik olarak tümörlerin yaklaşık \%50'sinde yumuşak doku kitlesi, \%814'ünde bitişik kemikteki basıya bağlı kortikal erozyon, \%8.3 periostal reaksiyon, \%5.5 kalsifikasyon ve çok nadir olarak da intramedüller tutulum bildirilmiştir. Bununla birlikte yaklaşık \%20 tümörde normal radyolojik bulgular tespit edilmiştir ${ }^{22,23}$. Çalışmamızda hastaların hiçbirinde kemik tutulumu olmayıp, direkt grafide \%83.3'ünde yumuşak doku kitlesi tespit edildi.

TKDHT tedavisi cerrahidir. Fleksör/ekstensör tendonlar, dijital arter/sinirler gibi komşu anatomik yapılar korunarak geride satellit lezyon bırakmayacak şekilde marjinal eksizyon yapılmalıdır. Cerrahi esnasında operasyon mikroskopu ya da cerrahi büyüteç kulanımı nüks oranını azaltmak için önemlidir ${ }^{20}$. Eğer kortikal erozyon gibi kemik tutulumu varsa küretaj önerilmektedir ${ }^{24}$.

Benign karakterine rağmen, cerrahi eksizyon sonrası lokal nüks oranı \%0-50 arasında değişmektedir ${ }^{17,20,25}$. 
Dev hücreli tümörlerin yüksek oranda nüksüne yol açabilecek potansiyel faktörler; yetersiz eksizyon, kemik invazyonu, histolojik muayenede sellülarite ve mitotik aktivite, nm 23 geni negatif tümör ve Tip II tümör olarak Al-Qattan tarafından tanımlanmıştır ${ }^{8}$. Ancak çoğu yazar tarafindan kötü cerrahi teknik nedeniyle tümörün tam olarak çıkarılmaması en önemli nüks nedeni olarak kabul edilmektedir ${ }^{9,13,26}$. Kotwal ve ark. yetersiz eksizyon yapılan ve yüksek mitotik aktivitesi olan hastalarda nüksü önlemek için radyoterapi önerilmişler ve radyoterapi sonrası $\%$ 4' lük bir nüks oranı bildirmişler ${ }^{27}$. Ancak bu konuda fikir birliği yoktur. Ikeda ve ark. nüksü önlemek için mikroskobik eksizyon yöntemini tanımlanmışlar ve ameliyat mikroskobu kullandıkları 18 hastanın yalnızca 1'inde nüks bildirmişlerdir ${ }^{28}$. Özalp ve ark. satellit lezyonları tespit edip çıarmak için cerrahi loop kullanılmasını ve çok sayıda nüksden sonra bile tekrar eksizyon önermişler$\mathrm{dir}^{21}$. Şu ana kadar nüksü önlemek için kanıtlanmış tek faktör cerrahi eksizyonun geride satellit lezyon bırakmayacak şekilde tam olarak yapılmasıdır.

Çalıșmamızda nüks oranı $\% 4.76$ olup bazı yayınlara kıyasla düşük bulundu. Williams ve ark. 213 hastanın ortalama 51 aylık takip süresinde nüks oranını \%12.6 olarak buldu ${ }^{29}$. Al Qattan 43 hastanın ortalama 48 aylık takip süresinde nüks oranını $\% 11.6$ olarak buldu (8). Özalp ve ark. marjinal eksizyon uyguladıkları 141 hastanın ortalama 43 aylık takip süresinde nüks oranın1 $\% 16$ olarak buldu ${ }^{21}$. Fotiadis ve ark. nüks oran1nı \%14.8 olarak buldu ve ameliyat esnasında mikroskop ya da büyütücü gözlük kullanımının nüks oranını düşürdüğünü ancak bunun istatiksel olarak anlamlı olmadığını buldu² 296 hastanın ortalama 12 yıl takip edildiği bir başka çalışmada nüks oranı $\% 8.3$ olarak bulunmuş. Bu çalışmada; lezyonun ekleme ulaşması, multinodüler olması, tendon erozyonuna neden olması, çepeçevre olması ve marjinal eksizyon yapılması nüksü arttıran faktörler olarak belirtilmiş. Ancak bu faktörlerden yanlızca ekleme ulaşan lezyonların ve tendon erozyonuna yol açan lezyonların nüksü arttırma açısından istatiksel olarak anlamlı olduğu bulun$\mathrm{muş}^{30}$. Çalışmamızda ortalama 6 yıllık takip süresinde nüks oranının düşük olması, ameliyatların geride satellit lezyon bırakmayacak şekilde büyütücü gözlük altında yapılmasıyla açıklanabilir. Ayrıca ameliyatların bir el cerrahisi kliniğinde, deneyimli el cerrahları tarafından yapılmış olması düşük nüks oranını açıklayabilir. Nüks gelişen 2 hastamızda (\%4.76) tümör volar taraftan başlayıp dorsal tarafa doğru uzanmaktaydı ve muhtemel nüks nedeni geride satellit lezyon kalmasıydı. Ancak literatürde 9 yıla kadar nüks bildirildiğinden hastaların takip edilmesi gerekir ${ }^{31}$.

TKDHT; aynı hastada birden fazla lokalizasyonda olabileceği gibi, aynı tendonun farklı lokalizasyonunda da olabileceği literatürde bildirilmiştir. Ushijima ve ark. 207 hastadan oluşan çalışmalarında, sağ el yüzük parmak ve sol ayak baş parmakta olmak üzere yanlız- ca bir hastada farklı lokalizasyonda yer alan iki tümör bildirmişlerdir ${ }^{26}$. Phallen ve ark. 56 hastadan oluşan serilerinde üç hastada farklı lokalizasyonda yer alan iki tümör bildirmişlerdir ${ }^{32}$. Park fleksör pollicis longus tendonundan kaynaklı ve iki farklı lokalizasyonda yer alan bir olgu bildirmiştir ${ }^{33}$. Hitora ve ark. aynı hastanın küçük parmağında iki faklı alanda lokalize olan bir olgu bildirmişlerdir ${ }^{34}$. Altaykan ve ark. aynı hastanın fleksör digitorum superficialis tendonu üzerinde farklı lokalizasyonlarda bir olgu bildirmişlerdir ${ }^{35}$. Çalışmamızda aynı hastada farklı lokalizasyonlarda ya da aynı tendonun farklı lokalizasyonlarında yer alan TKDHT olgusuna rastlanmamıştır.

Sonuç olarak TKDHT benign karakterine rağmen lokal agresif bir tümördür. Nüks oranlarını azaltmak için; büyütücü gözlük altında, geniş bir cerrahi sahada, titiz bir cerrahi uygulanmalıdır. Ameliyat esnasında büyütücü gözlük kullanmak komşu nörovasküler yapıların iyatrojenik yaralanmasını önlediği gibi, satellit lezyonların tespit edilip tümörün tam olarak eksizyonunu mümkün kılar ve nüks oranlarını düşürür. Ayrıca hem volar hem de dorsal bölgeye lokalize olan tümörlerde satellit lezyonları tespit edip çıkarmak için ayrı insizyonlar kullanılması da akılda bulundurulmalıdır.

\section{Kaynaklar}

1. Darwish FM, Haddad WH. Giant cell tumour of tendon sheath: experience with 52 cases. Singapore Med J Original 2008;49(11): 879-82.

2. Fotiadis E, Papadopoulos A, Svarnas T, Akritopoulos P, Sachinis NP, Chalidis BE. Giant cell tumour of tendon sheath of the digits. A systematic review. Hand 2011;6(3):244-9.

3. Chassaignac M. Cancer de la gaine des tendons.Gazette Hop Civils Mil 1852;47:185-6.

4. Targett JH. Giant cell tumors of the integument. Trans Pathol Soc Lond 1897;48:230-5.

5. Jaffe HL, Lichtenstein L, Sutro CJ. Pigmentedvillonodularsynovitis, bursitis and tenosynovitis: A discussion of the synovial and bursalequivalents of the tenosynovial lesions commonlydenoted as xanthoma, xanthogranuloma, giant cell tumor, or myeloplaxoma of the tendon sheath, with someconsideration of this tendon sheath lesionitself. Arch Pathol 1941;31:731-65.

6. Jones FE, Soule EH, Coventry MB. Fibrous xanthoma of synovium (giant-cell tumor of tendon sheath, pigmented nodular synovitis) A study of one hundred and eighteen cases. J Bone Joint Surg Am 1969;51(1):76-86.

7. Moore JR, Weiland AJ, Curtis RM. Localized nodular tenosynovitis: experience with 115 cases. J Hand Surg Am 1984;9(3):412-7.

8. Al-Qattan MM. Giant cell tumors of tendon sheath: classification and recurrence rate. J Hand Surg Br 2001;26(1):72-5.

9. Flandry F, Hughston JC. Pigmented villonodular synovitis. J Bone Joint Surg Am 1987;69(6):942-9.

10. Froimson AI. Benign solid tumors. Hand Clinics 1987;3(2): 213-7.

11. Glowacki KA, Weiss APC. Giant cell tumors of tendon sheath. Hand Clinics 1995;11(2): 245-53.

12. Hansen P, Nielsen PT, Wahlin AB. Pigmented villonodular synovitis of the extensor tendon sheaths in a child. J Hand Surg Br 1988;13(3):313-4. 


\section{Tendon Kılıfının Dev Hücreli Tümörü}

13. Byers PD, Cotton RE, Deacon OW, Lowy M, Newman PH, Sissons HA, Thompson AD. The diagnosis and treatment of pigmented villonodular synovitis. J Bone Joint Surg $\mathrm{Br}$ 1968;50(2):290-305.

14. Rao AS, Vigorita VJ. Pigmented villonodular synovitis (giantcell tumor of the tendon sheath and synovial membrane). A review of eighty-one cases. $\mathrm{J}$ Bone Joint Surg Am 1984;66(1):76-94.

15. Reilly KE, Stern PJ, Dale JA. Recurrent giant cell tumors of the tendon sheath. J Hand Surg Am 1999;24(6):1298-302.

16. Briet JP, Becker SJ, Oosterhoff TCh, Ring D. Giant cell tumor of tendon sheath. Arch Bone Jt Surg 2015;3(1):19-21.

17. Glowacki KA. Giant cell tumors of tendon sheath. J Hand Surg Am 2003;3(2):100-7.

18. Rukavina I, Caleta D. Giant-cell tumour of the tendon sheath: A review. OA Orthopaedics 2014;2(2):11.

19. Monaghan H, Salter DM, Al-Nafussi A. Giant cell tumor of tendon sheath (localised nodular tenosynovitis): clinicopathological features of 71 cases. J Clin Path 2001;54(5):404-7.

20. Adams EL, Yoder EM, Kasdan ML. Giant cell tumour of tendon sheath: experience with 65 cases. Eplasty 2012;12:42330.

21. Ozalp T, Yercan H, Kurt C, Ozdemir O, Coskunol E. Giant-cell tumors of the tendon sheath involving the hand or the wrist: an analysis of 141 patients. Acta Orthop Traumatol Turc 2004;38(2):120-4.

22. Karasick D, Karasick P. Giant cell tumor of the tendon sheath: spectrum of radiological findings. Skeletal Radiol 1992;21(4):219-24.

23. Booth KC, Campbell GS, Chase DR. Giant cell tumor of tendon sheath with intraosseous invasion: a case report. J Hand Surg Am 1995;20(6):1000-2.

24. Walsh EF, Mechrefe A, Akelman E, Schiller AL. Giant cell tumor of tendon sheath. Am J Orthop (Belle Mead NJ) 2005;34(3):116-21.

25. Suresh SS, Zaki H. Giant cell tumor of tendon sheath: case series and review of literature. J Hand Microsurg 2010;2(2):6771.
26. Ushijima M, Hashimoto H, Tsuneyoshi M, Enjoji M. Giant cell tumour of the tendon sheath (nodular tenosynovitis): A study of 207 cases to compare the large joint group with the common digit group. Cancer 1986;57(4):875-84.

27. Kotwal PP, Gupta V, Malhotra R. Giant cell tumour of the tendon sheath. Is radiotherapy indicated to prevent recurrence after surgery? J Bone Joint Surg 2000;82(4):571-3.

28. Ikeda K, Osamura N, Tomita K. Giant cell tumour in the tendon sheath of the hand: importance of the type of lesion. Scand J Plast Reconstr Surg Hand Surg 2007;41(3):138-42.

29. Williams J, Hodari A, Janevski P, Siddiqui A. Recurrence of giant cell tumors in the hand: a prospective study. J Hand Surg Am 2010;35(3):451-6.

30. Lancigu R, Rabarin F, Jeudy J, Saint Cast Y, Cesari B, Fouque PA, Raimbeau G. Giant cell tumors of the tendon sheaths in the hand: review of 96 patients with an average follow-up 12 years. Orthop Traumatol Surg Res 2013;99(4 Suppl):S251-4.

31. Jalgaonkar A, Dhinsa B, Cottam H, Mani G. Giant cell tumours of tendon sheath of hand: causes and strategies to prevent recurrence. Hand Surg 2011;16(2):149-54.

32. Phalen GS, McCormack LJ, Gazale WJ. Giant-cell tumor of tendon sheath (benign synovioma) in the hand. Evaluation of 56 cases. Clin Orthop 1959;15:140-51.

33. Park JW. Multiple separated giant cell tumors of the tendon sheath in a thumb. J Am Acad Dermatol 2006;54(3):540-2

34. Hitora T, Yamamoto T, Akisue T, Marui T, Nagira K, Ohta R, et al. Multicentric localized giant cell tumour of the tendon sheath: two separate lesions at different sites in a finger. Br J Dermatol 2002;147(2):403-5.

35. Altaykan A, Yildiz K, Hapa O, Cukur S. Multifocal giant cell tumor of the tendon sheath occuring at different localizations of the same tendon of a finger: a case report and review of the literature. Eklem Hastalik Cerrahisi 2009;20(2):119-23. 
